\title{
Pengaruh Pemberian Probiotik Terenkapsulasi Pada Pakan Ayam Petelur Terhadap Kolesterol telur Ayam
}

\author{
Zaraswati Dwyana, Ambeng, Nur Haedar, Nurul Nasikha \\ Departemen Biologi, Fakultas Matematika dan Ilmu Pengetahuan Alam \\ Universitas Hasanuddin \\ E-mail: zaraswatidwyana@gmail.com
}

\begin{abstract}
This study aims to determine the effect of probiotic administration encapsulated on the cholesterol content of egg laying eggs. Probiotics are given to laying hens (phase layer), once a day for 4 weeks orally. In this study a completely randomized design (CRD) was used with three treatments, namely, probiotic encapsulated lactic acid bacteria (BAL) (E1), commercial probiotics (E2), and without probiotics (EO) with 4 replications. The variables observed in this study were encapsulated probiotic viability, egg weight $(g)$, egg index (\%), and total egg cholesterol content $(\mathrm{mg} / \mathrm{g})$. The results showed that the viability of probiotic bacteria decreased by $3.34 \mathrm{cfu} / \mathrm{g}$ after 4 weeks of storage at $4 O C$. Average egg weight at E0; E1; and E2 are $62.63 \mathrm{~g}, 62.67 \mathrm{~g}$, and $64.15 \mathrm{~g}$. Average egg index at EO; $E 1$; and $E 2$ are $71.13 \%, 75.54 \%$, and $77.2 \%$. The average cholesterol content at E0; E1; and E2 is $3.75 \mathrm{mg} / \mathrm{g}, 3.25 \mathrm{mg} / \mathrm{g}$ and $3.25 \mathrm{mg} / \mathrm{g}$. The administration of encapsulated probiotics did not affect the quality of egg weight but it affected the egg index and total cholesterol content of egg laying eggs.
\end{abstract}

Kata kunci: Encapsulated probiotics, egg cholesterol

\section{PENDAHULUAN}

Probiotik adalah mikroorganisme hidup dalam tubuh yang sudah banyak dimanfaatkan terutama yang berkaitan dengan kesehatan. Selain mampu menghasilkan senyawa antimikroba, bakteri ini juga dapat meningkatkan sistim kekebalan tubuh baik itu pada manusia maupun hewan ternak. Bakteri probiotik juga memiliki kemampuan untuk menurunkan kadar kolesterol. Probiotik dapat memproduksi senyawa yang dapat menghambat sintesis lemak, memobilisasi atau mereduksinya sehingga disebut dengan penghasil antikolesterol. Probiotik Lactobacillus sp. mampu mengikat kolesterol yang terdapat pada aliran darah, kemudian dibawa ke usus halus untuk dibuang bersama feses. Mekanisme ini berdampak langsung terhadap penurunan kadar kolesterol yang dibawa darah ke ovarium sebagai tempat produksi kuning telur. Untuk mempertahankan sifat probiotiknya maka usaha untuk mempertahankan viabilitasnya terus dilakukan terutama dengan melakukan enkapsulasi dengan menggunakan media penyalut terhadap sel bakteri sehingga dapat bertahan dalam jangka waktu yang panjang, Dalam penelitian bertujuan untuk mengetahui kemampuan dari bakteri probiotik terenkapsulasi dalam menurunkan kualitas telur pada ayam petelur yang ditambahkan sebagai suplemen pada pakan ayam. 


\section{METODE PENELITIAN}

\section{Penyiapan Bakteri Probiotik}

Stok dari 5 isolat probiotik yang diperoleh dari koleksi Laboratorium Mikrobiologi diencerkan dengan cara, masing-masing stok diambil sebanyak 1 ose bulat kemudian dimasukkan ke dalam tabung rekasi yang masing-masing berisi $5 \mathrm{ml}$ aquades steril lalu divortex hingga homogen.

\section{Perbanyakan Bakteri Probiotik}

Bakteri probiotik hasil peremajaan diinokulasi ke dalam $50 \mathrm{ml}$ media MRSB diinkubasi selama 18 jam pada suhu $37{ }^{\circ} \mathrm{C}$, kemudian diinokulasi ke dalam $100 \mathrm{~mL}$ media MRSB dan diinkubasi selama 18 jam pada suhu $37^{\circ} \mathrm{C}$. Setelah masa inkubasi bakteri probiotik diendapkan dari media MRSB dengan cara disentrifugasi pada kecepatan 10000 rpm selama 10 menit.

\section{Enkapsulasi Probiotik dengan Metode Freeze Drying}

Biomassa sel bakteri probiotik yang diperoleh dimasukkan ke dalam $100 \mathrm{ml}$ aquades yang mengandung 20 gram susu skim, 2 gram maltodextrim, dan $1 \mathrm{ml}$ molase. Campuran dihomogenkan dengan pengadukan 500 rpm selama 30 menit. Campuran homogen dikeringkan dengan freeze dryer.

\section{Uji Viabilitas Enkapsulasi Probiotik}

Pengujian viabilitas sel bakteri asam laktat sesudah pembekuan kering (Freeze dryer) dilakukan pada media MRSA dengan metode tuang (plate count) dengan beberapa seri pengenceran. Sebanyak 1 $\mathrm{mL}$ hasil pengenceran ditanam ke dalam cawan petri steril dan dituang media MRSA diatasnya, digoyang-goyangkan agar media merata dengan kultur yang ditanam dan selanjutnya diinkubasi pada suhu $37^{\circ}$ Cselama 48 jam. Pengujian viabilitas probiotik terenkapsulasi dilakukan selama satu bulan dengan interval waktu 1 minggu.

\section{Pemberian Probiotik Enkapsulasi Pada Ayam Petelur}

Pada penelitian ini, pemberian probiotik pada ayam petelur (fase layer) dilakukan secara langsung (oral), sesuai dengan perlakuan yaitu E0 (tanpa probiotik), E1 (probiotik terenkapsulasi), dan E2 (probiotik komersil). Jumlah probiotik terenkapsulasi yang diberikan 0,1 g untuk setiap ekor ayam. Selanjutnya diberikan ke tiap kelompok ayam sesuai perlakuan masing-masing. Pemberian probiotik ini dilakukan setiap pagi hari selama 1 bulan.

\section{Pengujian Kualitas Telur Ayam Petelur}

Ayam petelur yang telah diberikan perlakuan berbeda diambil telurnya selama 6 hari setelah satu bulan pemberian perlakuan utuk dihitung bobot telur, lebar telur dan tinggi telur. Kemudian telur yang di uji kadar kolesterolnya adalah telur pada hari terakhir dari 6 hari pengambilan.

\section{Analisis Kandungan Kolesterol Telur Ayam Petelur}

Pengujian kandungan kolesterol telur Ayam petelur dilakukan di Balai Besar Laboratorium Kesehatan Makassar (BBLK Makassar). Dalam proses ekstaraksinya dilakukan di gedung Kimia Kesehatan BBLK Makassar dan pengujian kandunga kolesterol total dilakukan di laboratorium Patologi Klinik, BBLK Makassar. Perhitungan:

$$
\text { Kadar kolesterol }(\mathrm{mg} / \mathrm{gr})=\frac{\frac{y-a}{B} X \text { Faktor Pengenceran }}{\text { Berat Bobot }(\mathrm{g}) X 100}
$$

Keterangan :

$\mathrm{y}:$ absorbans contoh 

a : intersept
B : slope

\section{Parameter yang Diukur}

Parameter yang diamati selama penelitian ini adalah sebagai berikut :

1. Bobot telur ayam petelur

2. Indeks Telur meliputi tinggi telur dan lebar telur

3. Kandungan Kolesterol Telur

\section{Rancangan Penelitian}

Rancangan penelitian menggunakan desain Rancangan Acak lengkap dengan 3 perlakuan dan masing-masing perlakuan menggunakan ayam uji sebanyak 4 ekor (ulangan). Jika ternyata hasil ANOVA menunjukkan ada perbedaan nyata antar perlakuan, maka dilanjutkan dengan Uji Beda Nyata Terkecil (BNT). Adapun pemberian perlakuannya sebagai berikut :
$\mathrm{E}_{0} \quad$ : tanpa probiotik (Kontrol Negatif)
$\mathrm{E}_{1} \quad$ : Probiotik terenkapsulasi.
$\mathrm{E}_{2} \quad$ : Probiotik komersil (Kontrol Positif)

\section{HASIL DAN PEMBAHASAN}

\section{Enkapsulasi Probiotik dengan Metode Freeze Drying}

Untuk proses enkapsulasi pada penelitian ini dilakukan dengan menambahkan 20\% susu skim, maltodextrin $2 \%$ dan $1 \%$ molase. Setelah terbentuk larutan campuran yang terdiri dari aquades, susu skim, maltodekstrim dan molase, kemudian dilanjutkan dengan proses pembekuan. Setelah itu diperoleh serbuk (probiotik terenkapsulasi) yang berwarna putih kekuningan sebanyak 24,5 g.

Dengan penambahan bahan penyalut susu skim, maltodektrin, dan molase sebelum pembekuan dan pengeringan dilakukan dapat mengurangi kerusakan sel bakteri asam laktat akibat proses freezee drying. Penggunaan teknik freeze drying (beku kering) lebih menguntungkan dibanding teknik spray drying (semprot kering). Menurut Kailasapathy (2002) teknik spray drying membutuhkan suhu operasi yang tinggi sehingga kurang cocok diaplikasikan untuk enkapsulasi probiotik. Hal ini dibuktikan oleh Harmayani, dkk., (2001) bahwa penurunan viabilitas pada pembuatan sel kering dengan freezee drying berkisar $0.5-2$ siklus log, sedangkan dengan spray drying berkisar antara $2.5-4$ siklus log.

\section{Uji Viabilitas Probiotik Terenkapsulasi}

Uji viabilitas yang dilakukan pada penelitian ini untuk bakteri probiotik terenkapsulasi setelah proses freeze drying selama satu bulan dengan interval waktu 1 minggu, penyimpanan suhu kulkas $\left(4^{\circ} \mathrm{C}\right)$ (gambar1), terjadi penurunan viabilitas setiap minggunya. Setelah penyimpanan 1 bulan bakteri probiotik terenkapsulasi mengalami penurunan sebanyak kurang lebih 3,34 cfu/g. 


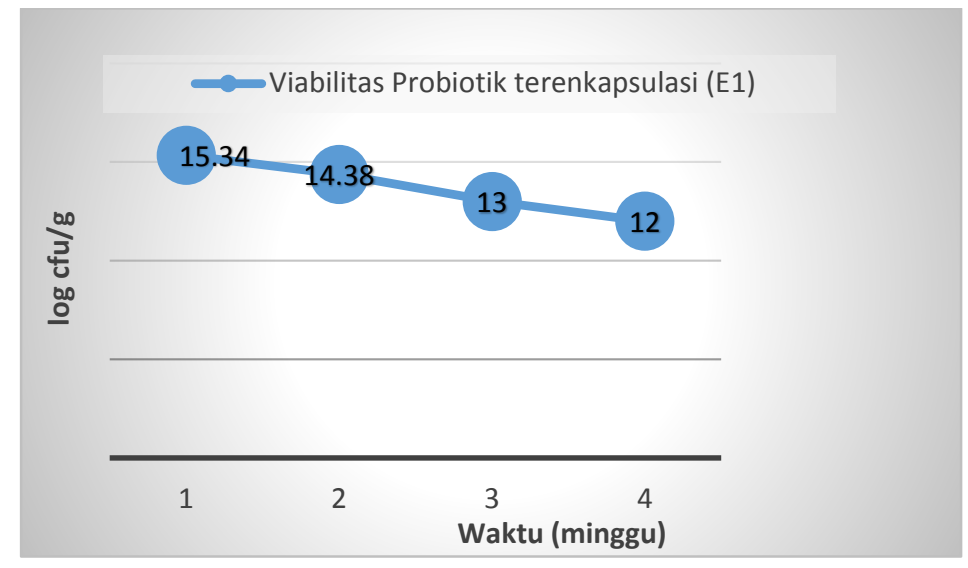

Gambar 1. Jumlah koloni pada uji viabilitas bakteri probiotik terenkapsulasi

Pada proses freeze drying, terjadi pembekuan $\left(-40^{\circ} \mathrm{C}\right)$ sehingga mengakibatkan hilangnya kestabilan sel selama pembekuan (Brashears and Gilliland, 1995), Jonhson and Etzel (1995) menjelaskan berkurangnya viabilitas juga dapat dipengaruhi saat tahap pedinginan sel dan medium untuk mencapai titik pembekuan, pembentukan es intra dan ekstra seluler, peningkatan konsentrasi solut, dan lama penyimpanan juga thawing.

\section{Pemberian Probiotik Enkapsulasi Pada Ayam Petelur}

Pemberian probiotik terenkapsulasi pada ayam petelur (fase layer) dilakukan selama 4 minggu. Pemberian dilakukan secara oral untuk semua perlakuan E0, E1, E2 .

\section{Pengaruh Perlakuan Terhadap Bobot Telur}

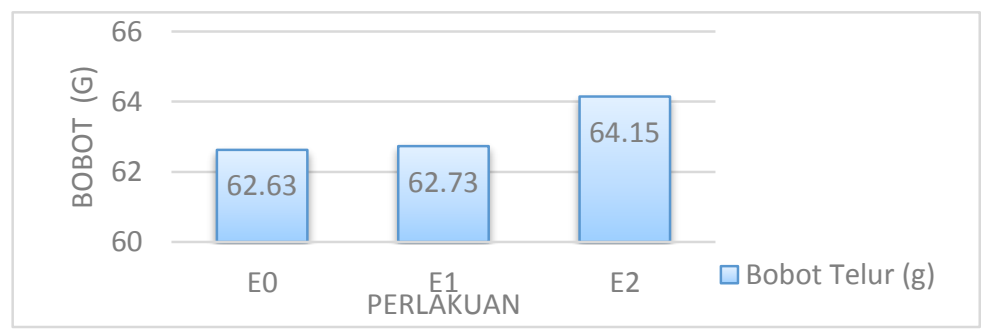

Gambar 2. Histogram nilai rata-rata pengaruh perlakuan tanpa probiotik (E0), probiotik BAL terenkapsulasi (E1), dan probiotik komersil (E2) terhadap bobot telur ayam petelur.

Pemberian probiotik, baik probiotik komersil maupun probiotik terenkapsulasi memiliki nilai yang lebih baik dibandingkan tanpa pemberian probiotik. Hal ini sesuai dengan pernyataan Istinganah (2013) bahwa penambahan probiotik dalam pakan cenderung dapat meningkatkan bobot telur karena bagian saluran pencernaan akan meningkatkan ketersediaan energi dan protein maupun zat makanan lainnya yang dibutuhkan untuk membentuk sebutir telur pada masa produksi.

\section{Pengaruh Perlakuan Terhadap Indeks Telur}

Berdasarkan hasil uji ANOVA diperoleh hasil yang menunjukkan bahwa $\mathrm{F}$ hitung > F tabel $(\mathrm{P}>0,05)$ yang berarti perlakuan E0, E1, dan E2 yang diberikan pada penelitian ini berpengaruh nyata terhadap indeks telur. Oleh karena itu, hasil yang diperoleh dilanjutkan dengan uji Beda Nyata Terkecil (BNT).Hasil uji BNT perlakuan dengan pemberian probiotik komersil dan perlakuan tanpa pemberian probiotik memiliki perbedaan nilai rata-rata indeks telur yang signifikan secara statistik. Penelitian 
mengenai indeks telur pernah dilaporkan oleh Mardiastuti (2004) bahwa indeks kualitas telur ayam Arab yang diberi ransum dedak gandum terfermentasi sebesar 78,61\%. Hubungan antara indeks telur dengan daya tetas ditemukan pada telur ayam dimana indeks telur yang ideal adalah 70\%-74\% (Yuwanta 2010). Jika dibandingkan dengan hasil penelitian yang diperoleh, nilai rata-rata indeks telur berdasarkan perlakuan sebagai berikut:

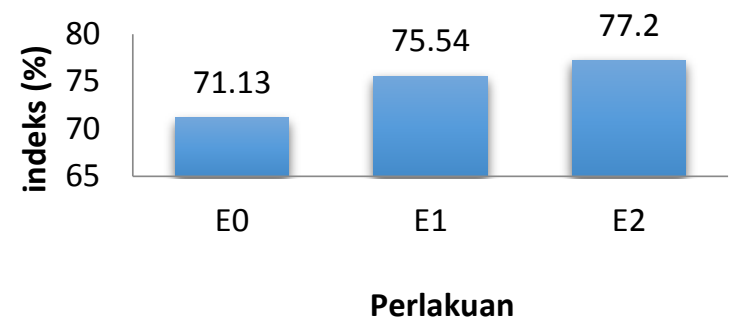

Gambar 3. Histogram nilai rata-rata indeks telur dengan perlakuan tanpa probiotik (E0), probiotik BAL terenkapsulasi (E1), dan probiotik komersil (E2).

\section{Pengaruh Perlakuan Terhadap Kolesterol Total Telur}

Telur ayam petelur yang memiliki kolesterol paling rendah adalah telur yang mendapat penambahan probiotik (probiotik BAL terenkapsulasi dan probiotik komersil) jika dibandingkan dengan perlakuan tanpa pemberian probiotik.

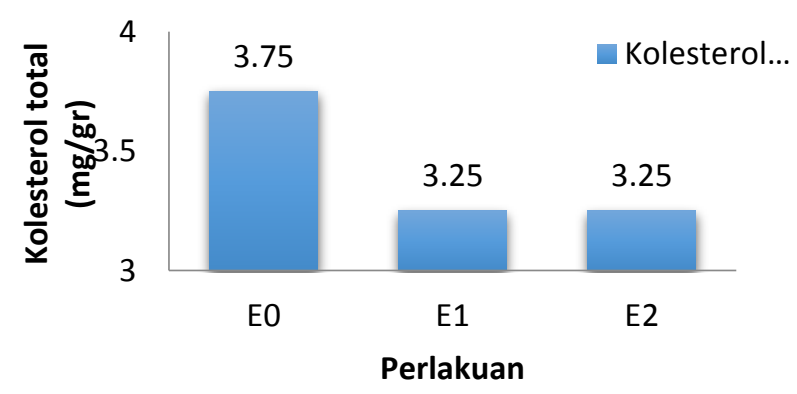

Gambar 4. Histogram nilai rata-rata kolesterol total telur ayam petelur dengan perlakuan tanpa probiotik (E0), probiotik BAL terenkapsulasi (E1), dan probiotik komersil (E2).

Penurunan kadar kolesterol total dikarenakan pemberian probiotik yang dapat meningkatkan penyerapan nutrisi dan produksi enzim bile salt hydrolise (BSH). Enzim BSH dapat menurunkan kadar kolesterol darah dan enzim lipase menurunkan trigliserida darah tanpa meninggalkan residu (Ljungh and Torkel, 2005). Hasil uji ANOVA yaitu F hitung > F tabel $(\mathrm{P}>0,05)$ yang berarti perlakuan E0, E1, dan E2 yang diberikan pada penelitian ini berpengaruh nyata terhadap kandungan kolesterol total telur ayam petelur. Uji BNT perlakuan tanpa probiotik signifikan secara terhadap pemberian probiotik BAL terenkapsulasi dan perlakuan probiotik komersil.

Pemberian probiotik dapat meningkatkan jumlah mikroba di dalam saluran pencernaan sehingga mampu menghambat sintesa kolesterol. Probiotik bakteri asam laktat mampu memproduksi enzim bile salt hydrolise (BSH) yang berfungsi memutus ikatan senyawa yang mensintesis kolesterol 
yaitu ikatan C-24 $\mathrm{NaCl}$ amida yang ada diantara asam ampedu dan asam amino pada garam ampedu terkonyugasi. Garam ampedu yang mengalami dekonyugasi akan di kembalikan ke hati dan dibuang melalui feses. Mekanisme ini berdampak langsung terhadap penurunan kadar kolesterol yang dibawa darah ke ovarium sebagai tempat produksi kuning telur (Surono, 2004). Kemampuan proiotik dalam menghabat sintesa kolesterol dimulai dengan terhambatnya kerja enzim hydroxi metyl glutaril KoA reduktase (HMG-KoA reduktase) yang berperan dalam pembentukan mevalonat dalam proses sintesis kolesterol, sehingga tidak terbentuknya kolesterol. Sesuai dengan Sudha, et, al., (2009) menyatakan penurunan kolesterol terjadi karena senyawa yang dihasilkan mikrobia berkompetisi dengan HMG-KoA untuk berikatan dengan enzim HMG-KoA reduktase.

\section{KESIMPULAN}

Pemberian probiotik terenkapsulasi dapat meningkatkan beberapa mutu telur ayam petelur, dan memberikan pengaruh terhadap kandungan kolesterol total dan indeks telur ayam petelur tetapi tidak berpengaruh terhadap bobot telur ayam petelur.

\section{DAFTAR PUSTAKA}

Brashears, M, M., and Gilliland, S, E. 1995. Survival During Frozen and Subsequent Refrigerated Storage Of Lactobacillus acidophilus Cells As Influenced By The Growth Phase. J. Dairy Sci. $78,2326-2335$

Harmayani, E., Ngatirah, Rahayu, ES, Utami, T. 2001. Ketahanan Dan Viabilitas Probiotik Bakteri Asam Laktat Selama Proses Pembuatan Kultur Kering Dengan Metode Freeze Drying Dan Spray Draying. Teknologi Dan Industri Pangan. 12:126-132.

Istinganah, L., Sigit, M., Ning, i. 2013. Penggunaan berbagai jenis probiotik dalam ransum terhadap produksi dan bobot telur ayam arab. Ilmiah Peternakan. 1(1): 338-346.

Kailasapathy, K. 2002. Micro-encapsulation of Probiotic Bacteria Technology and Potential Application. Current Issues Intestinal Microbiology. 3: 39-48.

Ljungh A., W. Torkel. 2005. Lactiz Acid Bacteria ad Probiotic. Curr.Issue Intestinal Microbiol. 7: 7390

Mardiastuti ES.. 2004. Pengaruh Penggunaan Dedak Gandum (Wheat Pollard) Terfermentasi Terhadap Kualitas Telur Ayam Arab (Skripsi). UNS Surakarta.

Sudha, M.R., Prashant, C., D. Kalpana, B. Sekhar, dan J. Kaiser. 2009. Probiotics as Complementary Therapy for Hypercholesterolemia. Journal Biology and Medicine. 1 (4): 4

Surono, IS. 2004. Probiotik dan Kesehatan. Tri Cipta Karya. Jakarta.

Yuwanta, T. 2010. Pemanfaatan Kerabang Telur. Program Studi Ilmu dan Industri Peternakan. Fakultas Peternakan. Universitas Gajah Mada. Yogyakarta. 